\title{
Two faces of shrimp aquaculture: commonising vs. decommonising effects of a wicked driver
}

\author{
Eranga K. Galappaththi ${ }^{1,3,4^{*}}$ and Prateep K. Nayak ${ }^{2,4}$
}

\author{
* Correspondence: \\ eranga.galappaththi@mail.mcgill.ca \\ ${ }^{1}$ Department of Geography, McGill \\ University, 805 Sherbrooke Street \\ West, Montreal, QC H3A OB9, \\ Canada \\ ${ }^{3}$ Postgraduate Institute of \\ Agriculture, University of \\ Peradeniya, Old Galaha Road, \\ Peradeniya 20400, Sri Lanka \\ Full list of author information is \\ available at the end of the article
}

\begin{abstract}
Much coastal fisheries literature supports the idea that shrimp aquaculture has the potential to cause considerable social and environmental destruction. The aim of the paper is to highlight the two faces of shrimp aquaculture as a wicked driver, emphasizing its potential role in activating systematic conversion of lagoon -based fisheries commons to non-commons and vice versa. We use the cases of aquacultureled privatisation in Chilika Lagoon, located in the Bay of Bengal area of India, and collective action surrounding shrimp aquaculture in Northwestern Sri Lanka. For both studies, data are collected through mixed research methods, including semi-directive interviews, focus group discussions, and participant observations. Our analysis shows clear evidence that shrimp aquaculture can potentially contribute to either making commons or losing commons depending on the context and influences of multi-level drivers. Aquaculture-led factors contributing to the process of losing commons in Chilika are: large-scale, individually owned aquaculture operations; encroachment of customary fishery commons; loss of commons rights (access and entitlements); breakdown of commons institutions; policy changes; caste politics and resource conflicts; ecological disturbances; change in fishing practices. In Sri Lanka, aquaculture related factors contributing to making commons are: coordinating discharge; built-in incentive for stewardship; multi-level commons institutions; collective decision-making; bottom-up management approach; mixed commons regime; and small-scale operations.
\end{abstract}

Keywords: Commons, Commonisation, Decommonisation, Shrimp aquaculture, India, Sri Lanka

\section{Introduction}

Aquaculture activities, especially shrimp and prawn cultivation, have gained prominence in the last three decades owing to the large-scale depletion of wild fish stocks and a growing worldwide demand for seafood (Naylor et al., 2000, Berkes et al., 2006, Cao et al., 2015, Pauly and Zeller, 2017). Alongside, many small-scale capture fishery systems have become aquaculture-oriented monoculture systems, causing shifts in fishing ecosystems, economies, cultures and societies worldwide (Naylor et al., 2000). Modifications in coastal habitats, the destruction of mangroves, and pollution and diseases from intensive culture (Huitric et al., 2002, Benessaiah and Sengupta, 2014) have contributed to the loss of local livelihoods and incomes and the collapse of fishery

(c) The Author(s). 2017 Open Access This article is distributed under the terms of the Creative Commons Attribution 4.0 International License (http://creativecommons.org/licenses/by/4.0/), which permits unrestricted use, distribution, and reproduction in any medium, provided you give appropriate credit to the original author(s) and the source, provide a link to the Creative Commons license, and indicate if changes were made. 
institutions. They have also resulted in poverty and the marginalization of a majority of small-scale fishers (Naylor et al., 2000, Nayak and Berkes, 2010, Marschke and Betcherman, 2016).

The growth of aquaculture has evaded these ecological, social and economic consequences. According to the 2016 FAO fish statistics report, world aquaculture production is increasing continuously and supply more than $44 \%$ of total global fish related demand (FAO, 2016). In Asia alone this increase is over 55 percentages. In 2014, world total aquaculture production stood at 73.8 million tones with an estimated first sale value of US $\$ 160.2$ billion. Since the 1990s, Asia remains as the biggest producer of shrimp products (Barnaby and Vincent, 2007, FAO, 2016). Shrimp exports augmented annually, causing an increased demand from major consumer countries like the USA, Japan and the European Union, and the massive supply of low-wage local laborers (Islam, 2008) together with a simultaneous reduction of about $50-80 \%$ of mangrove areas in major shrimp-producing countries (Bush et al., 2010). This boom in the aquaculture industry has resulted in social, economic and ecological damage (Naylor et al., 2000, Bush et al., 2010). In this context, shrimp aquaculture has become a "wicked" driver causing (un)predictable and highly variable impacts on local social-ecological systems (Berkes et al., 2003). Following Jentoft and Chuenpagdee (2009) we define wicked drivers as those for which there is no known technical solution, it is not clear when and how they create impact, and there are no right or wrong methods that can be determined scientifically to respond to these drivers.

Influenced by international market trends and the rising export price of shrimp and prawn, as well as complementary policy provisions, aquaculture has become one of the dominant drivers of change across fish-producing countries of the world (Cascorbi, 2004, FAO, 2015, Béné et al., 2016, Brown, 2016). The resulting marginalizing effects of shrimp aquaculture are explicitly recognized in fisheries and aquaculture literature (De Silva and Davy, 2010, Benessaiah and Sengupta, 2014, Militz and Foale, 2017). Some believe that exponential aquaculture growth relieves pressures on marine resources and the natural stock of fish and contributes positively towards ecosystem and habitat modification (Naylor et al., 2000, Frankic and Hershner, 2003, Costa-Pierce, 2010, Pauly and Zeller, 2017). Others believe aquaculture has the potential to enhance local livelihoods and human wellbeing, and to empower small producers (De Silva and Davy, 2010, Galappaththi and Berkes, 2015b, 2016). However, the success of aquaculture can come with significant social and environmental costs. Commercial aquaculture enthusiasts forget that much expansion has come at the cost of small-scale capture fisheries that previously occupied areas into which aquaculture has presently expanded (Nayak and Berkes, 2010, Benessaiah and Sengupta, 2014).

Nayak and Berkes (2011) capture these two viewpoints on shrimp aquaculture's contribution to ecosystem health and human wellbeing as processes of commonisation and decommonisation. "Commonisation is understood as a process through which a resource gets converted into a jointly used resource under commons institutions that deal with excludability and subtractability, and 'decommonisation' refers to a process through which a jointly used resource under commons institutions loses these essential characteristics" (Nayak and Berkes 2011: 132). Decommonisation helps understand the adverse effects of aquaculture as a driver that eventually contributes to the decline of customary capture fishery commons with immense social, economic, political, and 
ecological consequences. Inversely, the concept of commonisation is a lens to examine conditions in which aquaculture positively contributes to human wellbeing without causing significant harmful effects on the environment.

While decommonising effects of aquaculture are widespread and have received much attention in fishery literature, there is little or no published literature on aquaculture's potential as a factor in commonisation. This paper aims to address this gap by examining the two faces of aquaculture: its decommonising and commonising roles. We use two cases from South Asia (Sri Lanka and India) which offer evidence that shrimp aquaculture activities can potentially contribute to either a process of commonisation or decommonisation depending on the context and the influences of cross-scale drivers. In the case of the Bay of Bengal coast of India, we discuss an example of aquaculture-led privatisation, i.e., de facto control of customary capture fishery commons through their systematic encroachment in Chilika Lagoon for more than three decades to explain how it caused decommonisation. Using the case of Northwestern Sri Lanka, we discuss collective action (Ostrom, 2014) initiatives around small-scale shrimp aquaculture to consider aquaculture's role in creating the ground for commonisation that promises to reverse the process of decommonisation due to previously undertaken industrial shrimp aquaculture. We argue that aquaculture can strengthen the existing collective action to adapt to the changes in lagoon system or it can enable new forms of collective action fostering learning and innovation (Galappaththi et al., 2017). The challenge is to assess how, and if, key learnings from aquaculture's role in the commonisation processes in Sri Lanka can be implemented to reverse processes of decommonisation elsewhere, such as in Chilika Lagoon.

\section{Commonisation and decommonisation: The two faces of shrimp aquaculture}

Given the possibilities surrounding success and failure, the two faces of shrimp aquaculture are a growing reality. The fisheries literature shows an expanding debate over the positive and negative impacts of shrimp aquaculture (Lebel et al., 2002, De Silva and Davy, 2010, Nayak and Berkes, 2010, Galappaththi and Berkes, 2014). A considerable group of literature highlights the positive role of shrimp aquaculture with particular attention paid to its economic benefits (Kongkeo and Davy, 2010). Umesh et al. (2010) studied the small-scale shrimp farmers of Andhra Pradesh on the east coast of India, who adopted a cluster-based approach to achieving better returns from shrimp farming. Here, cluster-based approach refers to a group of farmers whose ponds are situated within a specified geographical locality and all ponds are relying on the same water source. These farmers acted collectively through aqua clubs that led to positive outcomes such as improved shrimp production, better shrimp quality, and stable relations among actors in the market chain and less environmental impact. Kongkeo and Davy (2010) documented a case from Chacheongsao Province in Thailand, depicting how backyard hatcheries helped sustain a fast-declining large-scale shrimp industry. They found that small-scale owner-managed shrimp farms do well due to a reliable source of quality shrimp seed.

However, the success of shrimp aquaculture is not without adverse consequences, and often involves tradeoffs. Nayak and Berkes (2010, p. 565) underscore the point that "coastal management is a zero-sum game. As one type of use increases, it does so at 
the expense of another. Aquaculture is not spreading in an 'empty' seascape and landscape, but in many instances displacing small fishers who were already using those areas" as commons. There is an extensive body of literature that supports this position by focusing on the environmental and social (including economic and political) impacts of shrimp/prawn aquaculture. Environmental impacts include coastal modifications, loss of mangroves, pollution, and disease problems (Dierberg and Kiattisimkul, 1996, Primavera, 1997, Huitric et al., 2002). Bhatta and Bhat (1998) recorded how the emergence of commercial shrimp aquaculture triggered problems in the management of estuaries in coastal Karnataka, India. Some well-documented socio-economic impacts of shrimp aquaculture include privatization of public lands, marginalization, rural unemployment, migration, food insecurity, loss of institutions, and social unrest and conflicts (Primavera, 1997, Naylor et al., 2000, Huong and Berkes, 2011, Nayak and Berkes, 2011, Benessaiah and Sengupta, 2014, Béné et al., 2016).

The adverse impact of aquaculture on capture fishery commons has been examined by Nayak and Berkes (2011) as a process of decommonisation, whereas a reverse process of aquaculture contributing to the management of the fishery as commons is seen as a process of commonisation. Nayak and Berkes (2011, p. 133) defined the concepts of commonisation and decommonisation whereby commonisation is understood as a process through which collective action, institutions, rules and norms regarding excludability and subtractability are put in place, and decommonisation refers to a process through which each of these tend to lose these essential characteristics. They explain that excludability pertains to the decision regarding who is a user (a question of exclusion and inclusion), whereas subtractability deals with the rules of resource distribution and allocation within the users without which exploitation by one user will reduce resource availability for others. Both these characteristics of commons add to their complexity (Feeny et al., 1990, Ostrom et al., 1999, Battersby, 2017), generate new contestations while helping solve existing ones, and help explain the perspective on commonisation and decommonisation. Both commonisation and decommonisation are continuous and potentially two-way, meaning that they can act to hinder each other by influencing the social, economic, ecological, political, historical and cultural aspects of an area. The resource can enter a process of commonisation; already-established commons or resources that are being commonised could also revert to decommonisation (Nayak and Berkes, 2011). Commonisation and decommonisation are useful lenses through which to analyze the two faces of aquaculture.

From a commonisation view, collectively managed resources work better than totally government-managed or privately managed resources; collective action is an effective means of confronting commons problems (Ostrom et al., 1999, Ostrom, 2007, Galappaththi and Berkes, 2014, Ostrom, 2014, Galappaththi and Berkes, 2015a). Galappaththi (2013) applied this approach to understand small-scale community-based aquaculture in Northwestern Sri Lanka. His findings suggest that large-scale aquaculture makes high returns on investment during the first few years, with the expectation that the shrimp farmers abandon their farming areas, move to new areas, and set up farms rather than establish sustainable practices and remain in one area. In contrast, small-scale community-based aquaculture farmers do not have the option of relocating. They cannot afford to act in unsustainable ways, as they are accountable to the community in which they live and do not have huge investment capacity (Galappaththi and 
Berkes, 2014, 2015a). Furthermore, Marschke et al. (2012) highlight how commons thinking can influence fisheries management including aquaculture.

In the context of decommonisation, aquaculture often involves the enclosure and privatization of resources - known characteristics of most neoliberal environments (Peluso, 2007). Belton et al. (2011) highlight the social implications of the enclosure and privatization of resources in Bangladesh; these resources were previously managed under common-property aquaculture regimes. Huong and Berkes (2011) examine how rapid development of aquaculture in Tam Giang Lagoon, Vietnam promoted privatization and reduced available lagoon water area for mobile-gear small-scale fishers. Nayak and Berkes (2011) report that approximately $60 \%$ of Chilika Lagoon remains under shrimp aquaculture (an activity declared illegal by the Supreme Court of India). The area for shrimp aquaculture comes from the forced encroachment of former commons under the control of small-scale fishers now held under elite capture (Béné, 2003, Nayak and Berkes, 2010), a situation akin to de facto privatization where higher caste, economically powerful, and political strong people have taken control of the fishing area. Enclosure and privatization in aquaculture are two of the main factors causing decommonisation. Globally, there are widespread examples of aquaculture contributing to the breakdown of customary commons institutions that were in charge of fishery management (Dewalt et al., 1996, Nayak and Berkes, 2010, Huong and Berkes, 2011, Nayak and Berkes, 2011, Benessaiah and Sengupta, 2014).

Consequently, the two faces of shrimp aquaculture, with its commonising and decommonising effects, create a conundrum that requires scholarly attention. While the bulk of the fisheries literature supports the idea that unregulated aquaculture can cause decommonisation (Pradhan and Flaherty, 2007, Nayak and Berkes, 2011, Benessaiah and Sengupta, 2014, Galappaththi and Berkes, 2015a), only a handful of studies suggests that there can be positive outcomes with large-scale aquaculture acknowledging their direct contribution to national economy (Nielsen et al., 2016). There are no straightforward "yes" or "no" answers to these assertions. Aquaculture can cause both commonisation and decommonisation; however, the scale at which their outcomes and impacts are felt is significant. While aquaculture's decommonising effects are undesirable from the ecosystem and human wellbeing perspective (Nayak and Berkes, 2010, Nayak and Berkes, 2011), positive outcomes associated with a process of aquaculture-led commonisation are desirable (Galappaththi and Berkes, 2015a). However, the former remains a well-studied area of fisheries research, while there has been little or no published literature on aquaculture's potential as a factor of commonisation. We acknowledge there are documented evidence for different forms of commonisation in fisheries (Sundström, 2013, Foley and McCay, 2014, Oviedo and Bursztyn, 2016), but so far not clearly in aquaculture, particularly in shrimp aquaculture except the unique Sri Lanka case study (Galappaththi and Berkes, 2015a, 2015b). Using commonisation and decommonisation as the two faces of aquaculture, we aim to address this gap in the literature. We use two cases - aquaculture-led privatization in the Bay of Bengal area of India and collective action around shrimp aquaculture in Northwestern Sri Lanka - to assess the potential of small-scale shrimp aquaculture for social-ecological sustainability and empowerment. 


\section{Methods}

Both case studies result from a mix of qualitative, participatory, and collaborative approaches (Johnson and Onwuegbuzie, 2004, Creswell, 2013). The Chilika case study is an ongoing longitudinal study since 2007 that focuses on the processes of socialecological change and their drivers in Chilika Lagoon, Bay of Bengal, India (Fig. 1). The Sri Lankan case study was a combination of two projects focused on value chains of shrimp aquaculture and governance of small-scale shrimp aquaculture that were conducted during 2007 to 2009 and then from 2012 to 2014, respectively. Both studies were based on data collection methods such as semi-structured interviews, participant observations, focus group discussions and meetings. The history of shrimp aquaculture in Chilika was explored through interactions with village elders, some of whom were actively involved in fish cooperatives and the federation. In the Sri Lankan case, key informant interviews with founders of the present management system, cooperative leaders, village elders, and government officials were conducted to gather historical data. Both studies were supplemented by the secondary data gathered from written records of shrimp farmers' associations and published government documents including government orders, development plans, legislative proceedings, and other policies concerning lagoon management at all levels of the district, state, and nation. Methodologically, the two case studies were mainly chosen because of compatibility in data collection approach and close time frame (2007-2014) that both studies were conducted.

\section{Results}

\section{Case study one: aquaculture-led privatization in India}

Chilika Lagoon is one of the largest lagoons in India and Asia, with an area of $1165 \mathrm{~km}^{2}$. Chilika is located in Odisha State on the east coast of India on the Bay of Bengal. Chilika is a globally important Ramsar site and a productive area with fish fauna adapted to a mix of seawater and freshwater. The shallow and sheltered waters of Chilika are appropriate for aquaculture, particularly for commercial production of tiger prawn (Penaeus monodon). A biodiversity hotspot, Chilika boasts a rare mix of estuarine, marine, and freshwater ecosystems.

Besides being a productive ecosystem, Chilika is known for its rich fishery resources. More than 400,000 fishers, representing seven fisher castes and their sub-castes (who

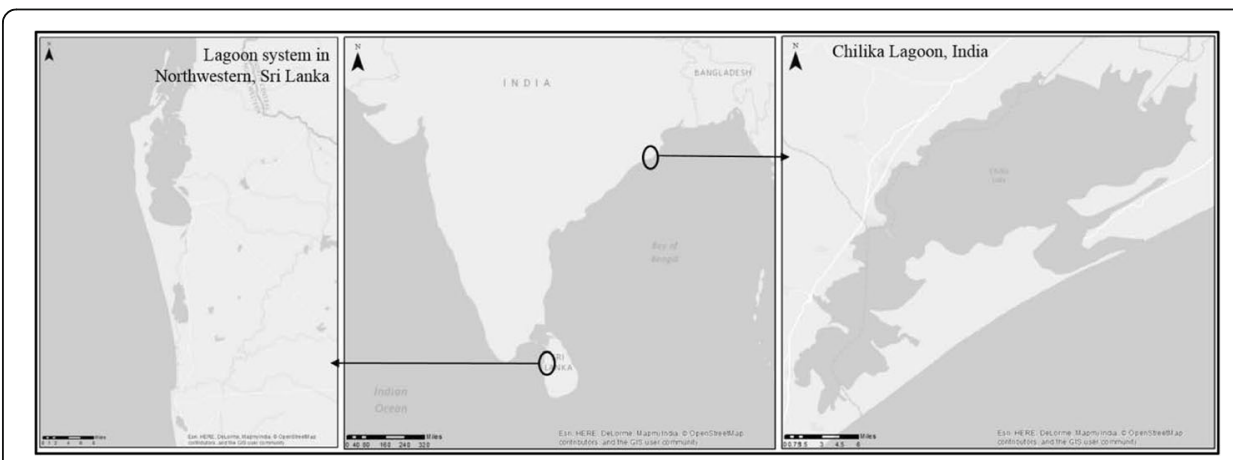

Fig. 1 Study areas in Sri Lanka and India 
are considered occupying the lower ranks in Hindu caste hierarchy), customarily managed the lagoon resources as commons and depended upon it for their livelihoods. The dominant fishing regime was capture fishery, and its management as commons was facilitated through village-level institutions. Fish cooperative and village committees, as well as regional-level fisher organisations (Chilika Machyajibi Mahasnagha or the fisher federations) are supported by locally crafted and agreed-upon use and management rules. The fishers in Chilika are caste-based. The vocation of traditional fisher groups is identified by their membership in certain Hindu castes. These fishers live in approximately 150 villages in and around Chilika. The lagoon ecosystem also supports a number of non-fisher village communities in the watershed area. These non-fisher communities engage in cultivation, depend on forests, and undertake other non-fishing occupations for their livelihoods. However, owing to large-scale forest degradation and the fact that land is not suitable for paddy cultivation, subsistence based on agriculture and forests is decreasing. Many non-fishers have turned to fishing, mainly aquaculture, as a source of income.

Since the 1970s, a boost in global fish demand and the shrinkage of total yield from capture fishery sources have brought aquaculture to the forefront and promoted the development of an international market for shrimp and prawn (Marshall, 2001, Delgado et al., 2003, Pradhan and Flaherty, 2007). Shrimp in India that had little value previously became "pink gold" (Kurien, 1991) and gained momentum through intensive aquaculture (Tovar et al., 2000) in the mid-1980s, putting India among the leading shrimp-exporting countries in the world. Chilika Lagoon was a natural area for tiger shrimp and caught on to the trend in the early 1980s. Investors and policymakers found it highly suitable for shrimp aquaculture.

As the international price of tiger shrimp tended upward, shrimp aquaculture became a major driver of change in Chilika Lagoon. Its development spread with great speed and intensity. Of a total of 140 fisher villages surveyed in 2009, 135 stated that they were adversely affected by shrimp aquaculture in Chilika. In the fishers' own words, "the onset of shrimp aquaculture in Chilika pushed us from the sky to beneath bare ground [Chingudi Chasa aamaku akasaaru patalaku theli dela]". The caste-based fishery commons received several impacts from aquaculture in Chilika.

Soon, an emergent culture of encroachment developed. Non-fishers (who are higher up in the Hindu caste hierarchy) and some fishers were supported by elites in the bureaucracy and political circles took up large-scale profit-driven aquaculture. In the process of encroachment, they took over customary capture fishery commons that were controlled by caste-based fishers and turned these into shrimp farms. The fishers soon found that the lagoon was virtually taken over by non-fishers and the "shrimp mafia." The study documented this claim by showing the encroachment on customary fishing areas in $91 \%$ of the lease-holding fisher villages of Chilika. There were many impacts of shrimp aquaculture on the social-ecological system of the lagoon (Table 1).

Significant changes in earlier government approach adapted to the management of Chilika Lagoon. Policy support for the caste-based capture fishery was withdrawn in support of the aquaculture-based fishery and the extension of rights to non-fishers. The state government introduced a new policy in 1991 which became a landmark piece of legislation because it created culture sources of fisheries in Chilika and, in addition to the customary capture practices of the caste-based fishers, legalized shrimp 
Table 1 Various impacts of shrimp aquaculture in Chilika Lagoon

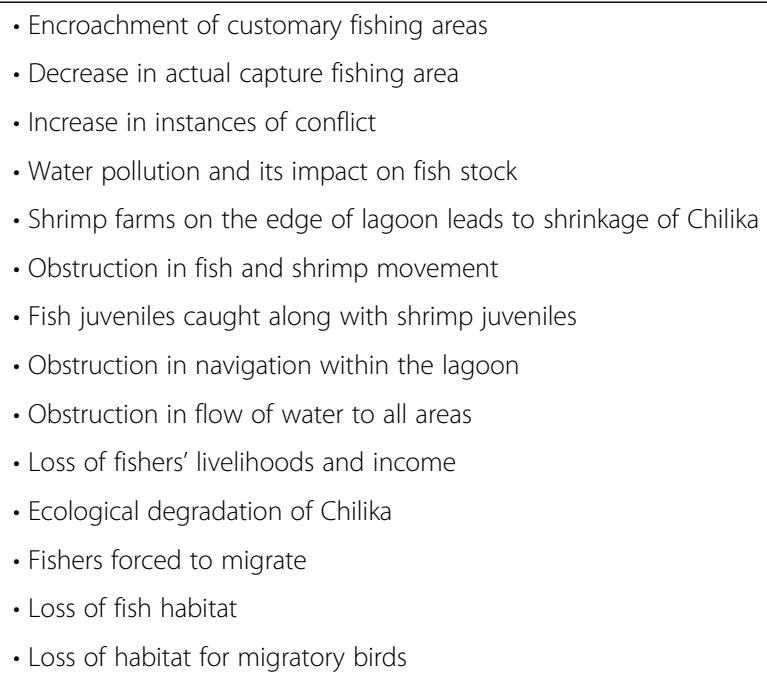

aquaculture. The legislation also made provisions for non-fisher caste villages to engage in aquaculture. In accordance, 6000 ha of customary fishing commons were withdrawn from caste-based fishers and reallocated to non-caste fishing villages. This loss of customary fishing areas by fisher villages was in addition to the area already under encroachment by the powerful shrimp mafia. The government even moved to bring in "holding companies" like the Tata Company to take up intensive shrimp aquaculture in Chilika.

Because of prolonged legal battles including fisher cooperatives' legal action against the 1991 policy in the Odisha State High Court, in 1993 shrimp aquaculture was banned by the Odisha State High Court. Further, shrimp aquaculture was banned by the Supreme Court of India in 1996 and the Odisha State Legislative Assembly House Committee in 1997, upholding the customary rights of caste-based fishers in Chilika. Finally, in 2001, the state government banned shrimp aquaculture in the lagoon and canceled the 1991 lease policy. However, in Chilika, such court decisions did not have much impact on the ground, as illegal shrimp aquaculture continued unabated as of 2014. According to conservative estimates, more than $60 \%$ of the lagoon fishing area remains under illegal shrimp aquaculture; according to other reports the figure is closer to $80 \%$ (Nayak and Berkes, 2010). Village fishing areas that were used as caste-based commons have essentially become "privatized" (Nayak and Berkes, 2010). The gap between higher court rulings and their implementation stems from the lack of accountability in implementing institutions, and showcases the clout of capitalist forces within the ruling class in Odisha. These developments have led to issues regarding fishers' access and entitlements. Aquaculture has also led to a steady erosion of institutions managing fishery commons in Chilika. With the loss of fish resources, most village fisher cooperatives went out of business.

\section{Case study two: collective action around shrimp aquaculture in Sri Lanka}

Tiger shrimp farming is the dominant coastal aquaculture operation in Sri Lanka; however, it is mostly restricted to the coastal Northwestern province and is inconsistently 
practiced in the eastern part of the country, mainly due to civil war (1980s to 2009) and the 2004 tsunami. As Fig. 1 shows, Northwestern shrimp aquaculture predominantly occurs in lagoon-based water systems. Puttalam Lagoon (32,000 ha), Mundal Lagoon (3600 ha) and Chilaw Lagoon (700 ha) are the three main lagoons in this part of the country (Pathirana et al., 2008). These three lagoons and other small bodies of water in the area are connected by a human-made Dutch canal, forming an interconnected common body of water. The Sri Lankan case study focuses on 32 lagoon-based coastal communities. These are small-scale shrimp farming communities, and a high level of family involvement (owner-managed) is consistent across them. Galappaththi (2013: 123-127) illustrates more information about scale of shrimp farming and nature of operations. Apart from shrimp farming, the most common livelihood activities are small craft fishing, cast net fishing, shrimp breeding, paddy farming, and coconut cultivation.

Shrimp aquaculture in Northwestern Sri Lanka started in the late 1970s with four large-scale multi-national companies with no government involvement. Because of the attractive profit margins, local people who were employed at these large firms started their own shrimp farms, applying the experience they had gained from employment with the shrimp companies. By the 1990s, a mix of large-, medium-, and small-scale shrimp farms became visible in the Northwestern region, with a total of about 1500 farms. Large-scale shrimp operations shifted from place to place through the conversion of mangrove areas (Gunawardena and Rowan, 2005) and coconut cultivation lands into shrimp farms (Cattermoul and Devendra, 2002). Disease outbreaks between 1988 and 1998 heavily impacted the shrimp industry in Sri Lanka. There were three major outbreaks: the Monodon Baculo Virus in 1988 and 1989, the White Spot Syndrome Virus (WSSV) in 1996 and both WSSV and the Yellow Head Virus in 1998. WSSV can kill shrimp within $24 \mathrm{~h}$, and spreads rapidly through the use of other aquatic animals (crustaceans, birds) as carriers. Because of the interconnected nature of the common body of water (the Dutch canal connecting all three lagoons) and the dependency of shrimp farmers on this body of water, shrimp diseases transmitted rapidly. Large-scale and most medium-scale farming operations went bankrupt, and small-scale shrimp producers struggled for survival (Galappaththi and Berkes, 2014).

During the 1990s, community-based institutions (shrimp farmers' associations) emerged at the village level to collectively respond to common challenges, such as drastic price fluctuations due to the impacts of disease outbreaks, as well as non-disease related factors including inflation. All shrimp farmers are represented by communitybased institutions known as shrimp farmers' associations ("Samithi" in the Sinhala language). Any individual within the community interested in undertaking shrimp farming must become a member of the shrimp farmers' association. The association collectively owns all potential areas for shrimp farming. It grants permission and makes area allocations to individuals for shrimp farming. Each association has its own rules to restrict new or potential shrimp farmers from farming in a community. For example, one rule is that newcomers must attend community association meetings continuously for six months before they are eligible for membership. Members are not allowed to sublease or rent their farms without the consent of the association. Galappaththi and Berkes (2014) discuss more about how shrimp farmers associations developed over time and about multi-level commons institutions. 
In 2003 and 2004, however, a significant system change in resource management took place due to the introduction of increased government control of shrimp-aquaculturerelated resource use. This change was a result of a collaborative effort on the part of shrimp farmers' associations and shrimp breeders' associations. During this period, shrimp farmers established a national-level shrimp aquaculture sector association known as the SLADA (Sri Lanka Aquaculture Development Association). They also requested that the Central Government (Ministry of Fisheries) assign a separate institution to monitor and support the shrimp aquaculture industry in their implementation of an action plan called the "Zonal Crop Calendar System." As a result, NAQDA (National Aquaculture Development Authority) became the main government institution responsible for the shrimp aquaculture sector and a North-Western Shrimp Aquaculture Monitoring Unit was established to facilitate the implementation of the action plan.

The primary objective of the Zonal Crop Calendar System was to manage shrimp disease. Because the spread of disease was linked to the common body of water (or the linkages between the lagoons through the Dutch canal), the Northwestern shrimp farming area was divided into five zones and 32 sub-zones. This zonal system was used to collectively decide who or which area (i.e., zone/sub-zone) could access the shared body of water at a stipulated time. A schedule/timetable (known as a crop calendar) was designed to manage communities' access to the common body of water. The crop calendar was developed on an annual basis with the participation of all stakeholders in the shrimp industry. This created opportunities for collective action in the area where collaborative processes facilitated meaningful negotiations amongst farmers and resulted in the effective resolution of conflicts. Using the crop calendar, shrimp farmers worked collaboratively and collectively, instead of competing, to overcome challenges.

In 2012 and 2013, there were about 600 shrimp farms in the Northwestern area, all of which depended on water from the lagoon-based interconnected body of water. Since there are collective rules and appropriate institutional arrangements in place, this body of water acts as a commons. Each shrimp farmers' association, with the support of government extension officers, monitors and enforces the rules that control pond water discharge. This monitoring is an ongoing process throughout the culture cycle. Discharge of used pond water is a major problem, as farmers release disease-infected water from shrimp ponds into the surrounding environment through the interconnected body of water. This individual action affects the ability of other shrimp farmers to continue farming without fear of disease. For example, if a particular farm is infected with diseases at the latter phase of production, the rational behavior of the cultivator is to harvest the infected pond before the quality of shrimp degrades, in order to make a better return on investment. However, if this farmer releases contaminated pond water to the common body of water, there is a high possibility of the disease spreading into other farms, which may not survive the disease (Galappaththi and Berkes, 2014, 2015a).

As of 2016, Sri Lankan Northwestern shrimp aquaculture remains a small-scale operation managed collaboratively through a mixed commons regime, i.e., private, communal and government ownership (Galappaththi and Berkes, 2015a). In the present arrangement, even privately owned or family-owned shrimp farms are managed under community rules. Lagoon-based capture fisheries still exists in Northwestern Sri Lanka, but not under shrimp aquaculture management regime (outside of the communal 
management institutions). The heart of this community-based shrimp aquaculture management system is a multi-layered structure of commons institutions (Galappaththi and Berkes, 2014) (Table 2). First, bottom-level sub-zones (usually communities) are represented by community associations which handle the regulation of routine shrimp farming activities. Second, these sub-zones aggregate into zones, forming zonal-level associations comprised of the leaders of sub-zonal associations. Their responsibility is to improve the infrastructure (roads, transportation, electricity supply) required for shrimp farming by working with divisional-level government authorities. Third, SLADA, as represented by the leaders of the zonal/sub-zonal associations, is responsible for the development of shrimp aquaculture in the area. Overall, SLADA closely collaborates with NAQDA in decision making. Effectiveness of this resource management system is partly reflected by the incremental growth of national shrimp aquaculture production since 2005, when the Zonal Crop Calendar System was first established (NAQDA, 2017).

\section{Discussion and conclusions}

Decommonisation in the context of shrimp aquaculture is globally widespread. In this context, aquaculture is usually seen as a driving factor of adverse environmental and social changes (Nayak and Berkes, 2011, D'Anna and Murray, 2015, Kassam and Dorward, 2017). The global shrimp trade (and the influential and lucrative international market price) combined with implementation of neoliberal approaches has remained a key driver of shrimp aquaculture since the late 1980s. Thus, from an economic perspective, shrimp aquaculture is an attractive profit-making opportunity for entrepreneurs. Nonetheless, the economic prosperity achieved through shrimp aquaculture comes at immense environmental, social, and institutional costs. While we know much about the adverse impacts of shrimp aquaculture and its role in causing various forms of decommonisation, examples of commonisation as it pertains to aquaculture are rare and constitute a less-explored area within small-scale fisheries literature (Galappaththi and Berkes, 2015b).

We argue, from a commons perspective, that aquaculture as a driver can cause both commonisation and decommonisation. Commonisation can occur when the process of farmers cooperate with each other by working collaboratively and collectively using commons institutions instead of competing, to solve commons problems. Our Sri Lankan case study provides an example of commonisation, i.e., how aquaculture farmers

Table 2 Multi-layered structure of commons institutions

\begin{tabular}{llll}
\hline Level & Institutions & Representation/members & Role \\
\hline Bottom & $\begin{array}{l}\text { Sub-zonal/community } \\
\text { associations (shrimp } \\
\text { farmers' association) }(\times 18)\end{array}$ & $\begin{array}{l}\text { All shrimp farmers in the } \\
\text { community }\end{array}$ & $\begin{array}{l}\text { Regulate routine shrimp-farming } \\
\text { activities (rules enforcement and } \\
\text { monitoring) }\end{array}$ \\
$\begin{array}{lll}\text { Zonal associations (×5) } \\
\text { Top }\end{array}$ & $\begin{array}{l}\text { Officers of the community } \\
\text { associations (bottom level) } \\
\text { (government) collaborative } \\
\text { decision-making body }\end{array}$ & $\begin{array}{l}\text { Improve infrastructure to support } \\
\text { community shrimp farmers (roads, } \\
\text { transportation, electricity supply) }\end{array}$ \\
& $\begin{array}{l}\text { SLADA- representatives from } \\
\text { both bottom and middle level }\end{array}$ & $\begin{array}{l}\text { Coordinate and facilitate crop } \\
\text { calendar development and major } \\
\text { decision making re: national-level } \\
\text { shrimp aquaculture management }\end{array}$ \\
& $\begin{array}{l}\text { NAQDA- government } \\
\text { representatives and extension } \\
\text { officers }\end{array}$ & \\
\hline
\end{tabular}


regulate themselves under a commons arrangement (e.g., collective action, and institutional and rule systems) to overcome challenges such as diseases, water distribution, pollution, conflict resolution and external linkages including policy and market. However, our Chilika case study depicts a process of decommonisation, i.e., how aquaculture triggers the disintegration of existing institutional, economic, social and cultural arrangements surrounding customary fishery commons. Here, aquaculture-led decommonisation took shape through the synergistic impacts of multiple factors such as global market trends, the global shrimp price, the creation of protected (restricted-access) areas, a change in government policy, a culture of encroachment, the erosion of fisher institutions and a change in fishing practices (Nayak and Berkes, 2010, 2011).

Aquaculture can make new (aquaculture) commons or break existing (fishery) commons (the two faces) by acting as a driver for both commonisation and decommonisation. In the case of Chilika Lagoon, fisheries have moved from being under a commons regime to an active phase of decommonisation. The situation is the opposite in Northwestern Sri Lanka, where decommonisation in the shape of privately owned large-scale aquaculture operations has given way to small-scale collective-actionoriented shrimp aquaculture that characterises a process of active commonisation. This resilient shrimp aquaculture governance system (mix regime; multi-level structure; robust community control using Samithi rules) make less feasible the occurrence of simultaneous (de)commonisation process in the same shrimp aquaculture management area (Galappaththi et al., 2017). Our cases together represent the two faces of shrimp aquaculture and critical insights into the role of shrimp aquaculture in achieving social-ecological systems sustainability (Berkes et al., 2003, Folke, 2016).

The commonisation process in Northwestern Sri Lanka is driven by multiple factors (Table 3). The zonal crop calendar system coordinates the discharge of pond wastewater. This mechanism is coordinated by the shrimp farmers' associations together with government institutions. The multi-level institutional structure of shrimp farmers' associations is collaboratively working with the government in decision making related to shrimp aquaculture management. A bottom-up management approach with government support is the distinguishing functional feature of this integrated institutional structure. A built-in financial and non-financial incentive for membership is a motivational driver for stewardship. Shrimp farmers develop this multi-level commons management system in cooperation with the government to effectively manage aquaculture $\mathrm{CPR}$ - an interconnected lagoon body of water. Sri Lankan small-scale shrimp aquaculture is run by the mixed commons regimes of private, communal and government (Galappaththi and Berkes, 2015a). An amalgamation of these factors makes a unique resource management system: aquaculture commons.

In reverse, the Chilika case offers insights into decommonisation led by a series of factors associated with shrimp aquaculture (Table 4). The overall change in the lagoon was characterized by a move from customary, community-based capture fishing to large-scale, individually owned shrimp aquaculture operations. As a direct consequence of shrimp aquaculture-led encroachments, the lagoon witnessed an extensive loss of fishers' access and entitlement rights (see Table 1 above). There was a breakdown of multi-level fishery institutions (e.g., village cooperatives, the fisher federation, the regional fish marketing federation) and collective decision-making arrangements. Influenced by rampant shrimp aquaculture, these changes became direct drivers of 
Table 3 Shrimp aquaculture-related factors contributing to the process of commonisation in Northwestern Sri Lanka

\begin{tabular}{|c|c|}
\hline Factors & Description \\
\hline Coordinating discharge & $\begin{array}{l}\text { - The zonal crop calendar is the primary mechanism for managing water } \\
\text { withdrawal and discharge from a common body of water by controlling } \\
\text { access to the body of water. Collectively agreed-upon rules are managed } \\
\text { by the community association to ensure implementation of the zonal crop } \\
\text { calendar. In shrimp-disease-infected situations, pond water is not allowed } \\
\text { to discharge to the external common body of water, and must follow } \\
\text { specific water treatment procedures within the farm. }\end{array}$ \\
\hline $\begin{array}{l}\text { Built-in incentive for } \\
\text { stewardship }\end{array}$ & $\begin{array}{l}\text { - Membership in a community association comes with both financial and } \\
\text { non-financial incentives coordinated through the community association, } \\
\text { such as: access to market and price-related information; free laboratory } \\
\text { testing of shrimp samples; partial compensation for financial losses (due to } \\
\text { shrimp diseases); and subsidies for disinfectants (wastewater treatment). }\end{array}$ \\
\hline $\begin{array}{l}\text { Multi-level institutional } \\
\text { structure }\end{array}$ & $\begin{array}{l}\text { - Horizontally and vertically integrated institutions use for shrimp aquaculture } \\
\text { management related decision-making and information-sharing purposes. } \\
\text { This multi-level institution structure has been introduced by shrimp farmers } \\
\text { with the support of the government. The top institutional layer is jointly } \\
\text { represented by the government and the sector association. }\end{array}$ \\
\hline Collective decision making & $\begin{array}{l}\text { - Decision-making is done collaboratively, by shrimp farmers and the } \\
\text { government. Collaboration can happen at all community, zonal and } \\
\text { national levels. Shrimp farmers make their community rules at } \\
\text { community associations. Other external stakeholder institutions } \\
\text { participate in decision making at the national level, during the } \\
\text { process of crop calendar development. }\end{array}$ \\
\hline $\begin{array}{l}\text { Bottom-up management } \\
\text { approach }\end{array}$ & $\begin{array}{l}\text { - Government institutions do not challenge community associations and } \\
\text { community rules. The feedback escalates from the community level to } \\
\text { the national level for major decision making like annual crop calendar } \\
\text { development. Better management practices are developed by the } \\
\text { government and adopted by the community-level associations. The } \\
\text { Fisheries Act of Sri Lanka recognizes and promotes the bottom-up } \\
\text { approach in managing the sector. }\end{array}$ \\
\hline Mixed commons regime & $\begin{array}{l}\text { - Shrimp farms are individually owned and managed under a community } \\
\text { association's rule. The government institution is involved in coordinating } \\
\text { and overseeing the crop calendar. The "private-communal-state" commons } \\
\text { management regime appears to be a feasible alternative to "big aquaculture" } \\
\text { and to the private property regime that it operates under. }\end{array}$ \\
\hline Small-scale operations & $\begin{array}{l}\text { - Small-scale shrimp aquaculture owners are families. The size of the } \\
\text { smallest pond observed was about } 0.2 \text { ha, while the largest was about } \\
0.8 \text { ha. }\end{array}$ \\
\hline
\end{tabular}

Source: Modified from Galappaththi and Berkes $(2014,2015 a)$ with additional support from primary data through recent field research

decommonisation. State policy changes in favour of shrimp aquaculture, caste politics (e.g., fishers and non-fishers based on their position in the Hindu caste hierarchy) and growing resource conflicts pushed the ongoing processes of decommonisation. This has resulted in the occupational displacement of customary fishers and out-migration by more than one-third adult fishers. On the ecological front, shrimp aquaculture had a deleterious effect on the biophysical, hydrological and geochemical processes of the lagoon, not only challenging its long-term sustainability but also jeopardizing its status as a commons (e.g., a commons does not exist if there is no physical resource present). Thus, a combination of these factors provides evidence of the possibility of shrimp aquaculture-led decommonisation.

Table 3 and Table 4 provide a baseline for understanding commonisation and decommonisation in the context of shrimp aquaculture. However, the list is not fully inclusive, as several other factors may result in similar experiences. Nonetheless, Table 3 offers a hopeful message for the future of aquaculture so long as certain conditions are met. 
Table 4 Shrimp aquaculture-led factors contributing to the process of decommonisation in Chilika Lagoon, India

\begin{tabular}{ll}
\hline Factors & Description \\
\hline Large-scale, individually owned & - Non-fishers and other powerful people/elites undertook aquaculture \\
aquaculture operations & activities in place of small-scale fishers. \\
& - Customary fishing areas under capture fishery commons became \\
& shrimp aquaculture ponds. \\
& - About $60-80 \%$ of the lagoon is under direct or indirect impact of \\
& shrimp aquaculture. \\
& - Non-fishers and the "prawn mafia" indulged in encroaching \\
& customary fishing areas for creating aquaculture farms. \\
Encroachment of customary & More than half of the total capture fishing area under \\
fishery commons & encroachment and about $80 \%$ of fisher villages reported \\
& encroachment of their fishing grounds.
\end{tabular}

Loss of commons rights

(access and entitlements)

Breakdown of commons institutions and collective decision making

Policy changes
- Loss of fishers' physical access to their fishing grounds led to the loss of their related rights to use, manage and exclude non-users, with serious implications for their legal entitlements.

- Locus of decision making control moved from local fishers to a centralised administrative control through the creation of state-level bureaucratic institutions for managing the lagoon and its affairs.

- Eighty-eight percent of village-level cooperatives became either dormant or dysfunctional without a steady flow of everyday fish.

- State policies favoring aquaculture: temporary legalization of shrimp aquaculture in the lagoon, ensuring the rights of nonfishers to engage in shrimp aquaculture, withdrawal of fishing areas from customary fishers and the making of allotments to non-fisher villages for shrimp aquaculture. (These areas continue to be held by non-fisher villages even though the policy was revoked in 1996.)

- Changes in lease policy and arrangements: a sudden increase in the annual lease fees (by 27\%) and lease to individuals, nonfisher castes and even government departments.

- Conservation focus: reallocation of customary fishing areas and their diversion for other uses such as the creation of protected areas that excluded many fisher villages from exercising their fishing rights.

Caste politics and resource conflicts

- The divide between the preferences for customary capturebased (traditional fisher castes) and shrimp aquaculture-based (non-fisher higher castes) fishing triggered caste conflicts around fishery resource management.

Ecological disturbances and degradation

- Permanent enclosures created by shrimp aquaculture farms in the lagoon restricted free flow of both fresh (from rivers) and saline (from the sea) water, nutrients, natural fish seed and feed, and movement of fish, creating biophysical, hydrological and geochemical disturbances in the lagoon.

Change in fishing practices
- A predominantly multi-species-oriented capture (a combination of mobile and fixed-gear) fishery system was turned into a single specie-based shrimp aquaculture system.

- Synthetic nets took precedence over traditionally made fishing gear mainly built from forest products.

- Group-based fishing activities under the commons management took a backseat as fishing became more or less an individual enterprise.

Source: Modified from Nayak and Berkes (2011) with data from additional field research during 2012 through 2015

We recognize that the successes of aquaculture (e.g., unregulated, large-scale/industrial, profit/export market-driven kind) can come at significant social and environmental costs. Given this reality, the message in Table 4 is no less significant as it offers a set of factors that are better avoided, as they promote decommonisation. We suggest that both Table 3 and Table 4 teach a key strategy, i.e., to capitalize on the factors of commonisation in Table 3 to tackle the factors of decommonisation in Table 4. How we 
can best implement this depends on the social-ecological and political contexts within which shrimp aquaculture is practiced. For example, in Northwestern Sri Lanka, smallscale shrimp farmers are empowered by their experience working for large-scale aquaculture companies (a failed example due to the effects of decommonisation). If the big companies had continued their operations, the Sri Lankan case would have produced far greater decommonising effects on the small-scale customary fishery commons in the Puttalam, Mundal, and Chilaw lagoons. Using this case study, we argue that lessons learnt from aquaculture-led decommonisation in a particular social-ecological context (e.g., Chilika Lagoon, Bay of Bengal, India) can be used to promote a process of commonisation.

Turning a process of decommonisation into commonisation involves questions about issues regarding excludability and subtractability. "Tragedy of the commons" (Hardin, 1968) describes how freedom to access the commons can cause the whole system to fail (Feeny et al., 1990, Ostrom et al., 1999, Poteete et al., 2010, Battersby, 2017). In an aquaculture context, this tragedy takes shape through the loss of fishers' customary access to control by powerful external actors whose exclusion becomes tricky (an excludability concern), and their hostile actions around reshuffling rules of resource (mis)use, (re)distribution, (re)allocation and (over)exploitation reduce resource availability for the customary fishers (a subtractability concern). In our case study contexts, a similar tragedy became evident due to the overuse of environmental resources as inputs and the discharge of wastewater into the environment by industrial aquaculture groups in Northwestern Sri Lanka (Bournazel et al., 2015, Harkes et al., 2015) and the encroachment of customary capture fishery commons by groups of higher caste non-fishers and regulation of the use of the lagoon space in Chilika Lagoon, India (Nayak and Berkes, 2011). Solving this "tragedy" should start by fixing the excludability and subtractability problems in novel ways (Feeny et al., 1990, Ostrom, 1990, Ostrom et al., 1999, Nayak and Berkes, 2011, Galappaththi and Berkes, 2015a). For example, in the Sri Lankan case, fixing the excludability and subtractability problems meant transferring the power to control resource access back to the small-scale shrimp farmers and strengthening their capacity to formulate and enforce rules of subtraction, exclusion and inclusion. However, such a shift has yet to take place in Chilika Lagoon. Consequently, the aquaculture tragedy, in the form of subtractability and excludability problems, remains unresolved here.

Collaboration, cooperation, and collective action are essential elements of successful commons management (Poteete et al., 2010). However, collaboration over competition, and cooperation over contestation, are not easy to achieve without engaging in processes of negotiation, partnership, relationship and institutional linkages across multiple levels. Sri Lankan shrimp aquaculture provides evidence of transforming from aquaculture as a competitive and highly contested game to it being a collaborative and collective action-oriented game. For example, the community association is the fundamental institution that promotes collective action at the bottom (sub-zonal) level. At zonal and national levels, the multi-layered institutional structure works as a mechanism for collective action. This demonstrates the fact that aquaculture has the potential to create collective action and commons institutions if played using the rules of collective action (De Silva and Davy, 2010, Galappaththi and Berkes, 2015b). Otherwise, it creates environmental injustice with grossly decommonising effects (Nayak and Berkes, 2010, 2011). 


\section{Summing up: possible way forward}

Given the threats and opportunities, the two faces of shrimp aquaculture warrant further scholarly attention. This will include an examination of conditions that promote aquaculture-led commonisation and possible ways of addressing the key factors that create opportunities for decommonisation. In particular, there is an urgent need to expand on case examples.

Our case analysis offers two alternate scenarios. Scenario one suggests that, if implemented judiciously, a combination of small-scale and non-intensive aquaculture and capture fisheries within a commons framework has tremendous social-ecological potential, as in the case of Northwestern Sri Lanka. First, it helps to avoid such ecologically damaging activities as the conversion of mangrove and coconut cultivation areas into shrimp ponds and the contamination of wetland habitats with disease and pollution, and their resulting environmental consequences. Second, it creates economic opportunities for a large number of individuals and families to engage in income-generating operations instead of having benefits flow to only a handful of households that have investment capacity. Third, this practice is known to be socially acceptable and culturally appropriate because it is rooted in local history, customs and practices. In addition to making social and cultural sense, it is more equitable in comparison to large-scale individually owned aquaculture systems. Forth, a commons framework for including aquaculture in fisheries governance is politically empowering as it creates opportunity and space for everyone involved to participate in the institutional and decision making processes. Through this route, aquaculture can potentially strengthen processes of commonisation in the governance of local fisheries instead of disrupting existing institutional processes through decommonisation.

In scenario two, unabated, large-scale and intensive aquaculture that aims to replace customary capture fishery systems already in place will be detrimental to the entire social-ecological system, as seen in the case of Chilika. First, ecological consequences will include conversion of multi-species and biodiverse ecosystems into monoculture environments with alterations in biophysical, hydrological and geochemical processes. Second, local capture fishery-based economic and livelihood systems will collapse into market-driven, externally influenced and out-migration dependent systems. The smallscale fishers will suffer the consequences of poverty and food insecurity, making them further vulnerable to marginalisation. Third, rife with inequity and negative power dynamics, it will contribute to growing contestations, conflicts and loss of community cohesion and cooperation, resulting in the local fishery losing its social and cultural identity. Forth, local fisheries governance systems will give way to a combination of centralized top-down state management and de facto privatization through the "elite capture" of customary fishing grounds (Nayak and Berkes, 2010), resulting in political disempowerment of small-scale fishers and their exclusion from decision making processes. Overall, this scenario implies that such aquaculture practices will cause an accelerated process of decommonisation of local fishery commons.

The two scenarios offer further insights into the initial depiction of the two faces of aquaculture. One scenario suggests the possibility of both aquaculture and capture fishery working together in tandem within a commons approach for social-ecological sustainability, whereas the other rests on the principle of exclusion whereby aquaculture thrives by displacing small-scale fishery systems that are already in place. How, then, 
do we minimize the decommonising effects and promote the commonising impacts of shrimp aquaculture? To do this, a series of policy provisions, awareness-building measures, management and governance innovations, institutional arrangements, rules and norms, and multi-level negotiations will be required. Feasibility of two scenarios will open avenues for more policy related research opportunities on shrimp aquaculture.

Following Nayak and Berkes (2010), we extend the argument that aquaculture has the potential to enhance social-ecological processes and their outcomes if played as a win-win game that respects local rights and livelihoods, as well as ecosystem processes. Or it can be played as a win-lose game that creates environmental injustice and processes of social-ecological marginalisation. As a win-win game, aquaculture will become a driver of commonisation, as in the case of Northwestern Sri Lanka. Conversely, it will act as a driver of decommonisation when played as a win-lose game, as in the case of the Bay of Bengal, Chilika Lagoon, India. Transitioning from "aquaculture as a zerosum game" to "a win-win game" will depend largely on how effectively we strike a balance between the two mutually exclusive faces of aquaculture - commonisation and decommonisation. The challenge, then, is to assess how, and if, key lessons from aquaculture's role in the commonisation processes in Sri Lanka (and similar cases elsewhere) can be implemented to reverse processes of decommonisation elsewhere, such as the case of Bay of Bengal, Chilika Lagoon, India.

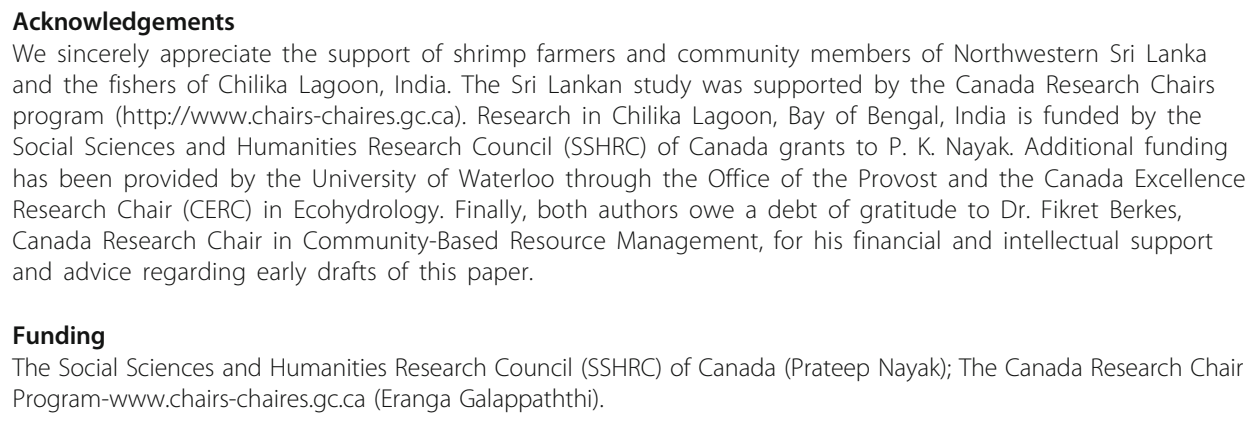
and the fishers of Chilika Lagoon, India. The Sri Lankan study was supported by the Canada Research Chairs program (http://www.chairs-chaires.gc.ca). Research in Chilika Lagoon, Bay of Bengal, India is funded by the Social Sciences and Humanities Research Council (SSHRC) of Canada grants to P. K. Nayak. Additional funding has been provided by the University of Waterloo through the Office of the Provost and the Canada Excellence Research Chair (CERC) in Ecohydrology. Finally, both authors owe a debt of gratitude to Dr. Fikret Berkes, Canada Research Chair in Community-Based Resource Management, for his financial and intellectual support and advice regarding early drafts of this paper.

Funding

The Social Sciences and Humanities Research Council (SSHRC) of Canada (Prateep Nayak); The Canada Research Chair Program-www.chairs-chaires.gc.ca (Eranga Galappaththi).

\section{Authors' contributions}

Both authors' made a substantial contribution to this paper by providing input on the concept and design, revising critical intellectual content, and by giving final approval for the version to be published.

\section{Competing interests}

The authors declare that they have no competing interests.

\section{Publisher's Note}

Springer Nature remains neutral with regard to jurisdictional claims in published maps and institutional affiliations.

\section{Author details}

${ }^{1}$ Department of Geography, McGill University, 805 Sherbrooke Street West, Montreal, QC H3A 0B9, Canada. ${ }^{2}$ School of Environment, Enterprise and Development, University of Waterloo, 200 University Avenue West, Waterloo, ON N2L 3G1, Canada. ${ }^{3}$ Postgraduate Institute of Agriculture, University of Peradeniya, Old Galaha Road, Peradeniya 20400, Sri Lanka.

${ }^{4}$ Natural Resources Institute, University of Manitoba, 70 Dysart Road, Winnipeg, MB R3T 2N2, Canada.

Received: 22 August 2016 Accepted: 6 June 2017

Published online: 18 October 2017

\section{References}

Barnaby, J, A Vincent. 2007. An assessment of the sustainability of shrimp purchasing at UBC. The University of British Colombia Sustainable Seafood Project- Phase II. Vancouver: University of British Colombia.

Battersby, S. 2017. News feature: Can humankind escape the tragedy of the commons? Proceedings of the National Academy of Sciences 114:7-10.

Belton, B, M Karim, S Thilsted, W Collis, M Phillips. 2011. Review of aquaculture and fish consumption in Bangladesh. The WorldFish Center 2011:71. 
Béné, C. 2003. When fishery rhymes with poverty: A first step beyond the old paradigm on poverty in small-scale fisheries. World Development 31:949-975.

Béné, C, R Arthur, H Norbury, EH Allison, M Beveridge, S Bush, L Campling, W Leschen, D Little, D Squires. 2016. Contribution of fisheries and aquaculture to food security and poverty reduction: Assessing the current evidence. World Development 79:177-196.

Benessaiah, K, R Sengupta. 2014. How is shrimp aquaculture transforming coastal livelihoods and lagoons in Estero real, Nicaragua?: The need to integrate social-ecological research and ecosystem-based approaches. Environmental Management 54:162-179.

Berkes, F, J Colding, C Folke.2003 Navigating social-ecological systems: Building resilience for complexity and change. New York: Cambridge University Press.

Berkes, F, T Hughes, R Steneck, JA Wilson, D Bellwood, B Crona, C Folke, L Gunderson, H Leslie, J Norberg. 2006. Globalization, roving bandits, and marine resources. Science 311:1557-1558.

Bhatta, R, M Bhat. 1998. Impacts of aquaculture on the management of estuaries in India. Environmental Conservation 25:109-121.

Bournazel, J, MP Kumara, LP Jayatissa, K Viergever, V Morel, M Huxham. 2015. The impacts of shrimp farming on landuse and carbon storage around Puttalam lagoon, Sri Lanka. Ocean \& Coastal Management 113:18-28.

Brown, K. 2016. Resilience, development and global change. New York: Routledge.

Bush, SR, PA Van zwieten, L Visser, H Van dijk, R Bosma, WF De boer, M Verdegem. 2010. Scenarios for resilient shrimp aquaculture in tropical coastal areas. Ecology and Society 15:15.

Cao, L, R Naylor, P Henriksson, D Leadbitter, M Metian, M Troell, W Zhang. 2015. China's aquaculture and the world's wild fisheries. Science 347:133-135.

Cascorbi, A. 2004. Farm-raised shrimp worldwide overview. Seafood watch seafood report: Farmed shrimp, final report.

Cattermoul, N, A Devendra. 2002 Effective management for biodiversity conservation in Sri Lankan coastal wetlands, a measurement of the ecological footprint of shrimp farming in the Chilaw lagoon area. Portsmouth: University of Portsmouth Cemare.

Costa-pierce, BA. 2010. Sustainable ecological aquaculture systems: The need for a new social contract for aquaculture development. Marine Technology Society Journal 44:88-112.

Creswell, JW. 2013. Research design: Qualitative, quantitative, and mixed methods approaches. New York: Sage publications.

D'anna, L, G Murray. 2015. Perceptions of shellfish aquaculture in British Columbia and implications for well-being in marine social-ecological systems. Ecology and Society 20:57

De silva, SS, FB Davy. 2010. Success stories in Asian aquaculture. International Development Research Centre. Ottawa: Springer.

Delgado, C. L., Wada, N., Rosegrant, M. W., Meijer, S. \& Ahmed, M. 2003. Outlook for fish to 2020: meeting global demand, Intl food policy res inst.

Dewalt, BR, P Vergne, M Hardin. 1996. Shrimp aquaculture development and the environment: People, mangroves and fisheries on the Gulf of Fonseca, Honduras. World Development 24:1193-1208.

Dierberg, FE, W Kiattisimkul. 1996. Issues, impacts, and implications of shrimp aquaculture in Thailand. Environmental Management 20:649-666.

FAO. 2015. Assessing climate change vulnerability in fisheries and aquaculture: Available methodologies and their relevance for the sector, by Cecile Brugère and Cassandra de young. Rome, Italy: FAO Fisheries and Aquaculture Technical Paper No. 597.

FAO. 2016. The state of world fisheries and aquaculture 2016, contributing to food security and nutrition for all. Rome: Food and Agriculture Organization of the United Nations.

Feeny, D, F Berkes, BJ Mccay, JM Acheson. 1990. The tragedy of the commons: Twenty-two years later. Human Ecology 18:1-19.

Foley, P, B Mccay. 2014. Certifying the commons: Eco-certification, privatization, and collective action. Ecology and Society 19:28.

Folke, C. 2016. Resilience (republished). Ecology and Society 21: 44

Frankic, A, C Hershner. 2003. Sustainable aquaculture: Developing the promise of aquaculture. Aquaculture International 11:517-530.

Galappaththi, E. 2013. Community-based Shrimp Aquaculture in Northwestern Sri Lanka. Master of natural resources management. Winnipeg: University of Manitoba.

Galappaththi, E. and Berkes, F. 2015a. Drama of the commons in small-scale shrimp aquaculture in northwestern, Sri Lanka. International Journal of the Commons, 9, 347-368.

Galappaththi, E, F Berkes, J Ford. 2017. Climate change adaptation efforts in coastal shrimp aquaculture: A case from northwestern Sri Lanka. FishAdapt: Global Conference on Climate Change Adaptation for Fisheries and Aquaculture. Rome: FAO.

Galappaththi, EK, F Berkes. 2014. Institutions for managing common-pool resources: The case of community-based shrimp aquaculture in northwestern Sri Lanka. Maritime Studies 13:1-16.

Galappaththi, E. K. and Berkes, F. 2015b. Can co-management emerge spontaneously? Collaborative management in Sri Lankan shrimp aquaculture. Marine Policy, 60, 1-8.

Galappaththi, EK, SS Kodithuwakku, IM Galappaththi. 2016. Can environment management integrate into supply chain management? Information sharing via shrimp aquaculture cooperatives in northwestern Sri Lanka. Marine Policy 68:187-194.

Gunawardena, M, J Rowan. 2005. Economic valuation of a mangrove ecosystem threatened by shrimp aquaculture in Sri Lanka. Environmental Management 36:535-550.

Hardin, G. 1968. The tragedy of the commons. Science 162:1243-1248.

Harkes, I, A DRENGSTIG, M KUMARA, J JAYASINGHE, M HUXHAM. 2015. Shrimp aquaculture as a vehicle for climate compatible development in Sri Lanka. The case of Puttalam lagoon. Marine Policy 61:273-283.

Huitric, M, C Folke, N Kautsky. 2002. Development and government policies of the shrimp farming industry in Thailand in relation to mangrove ecosystems. Ecological Economics 40:441-455. 
Huong, T, F Berkes. 2011. Diversity of resource use and property rights in tam Giang lagoon, Vietnam. International Journal of the Commons 5:130-149.

Islam, MS. 2008. In search of "white gold": Environmental and agrarian changes in rural Bangladesh. Society and Natural Resources 22:66-78.

Jentoft, S, R Chuenpagdee. 2009. Fisheries and coastal governance as a wicked problem. Marine Policy 33: 553-560.

Johnson, RB, AJ Onwuegbuzie. 2004. Mixed methods research: A research paradigm whose time has come. Educational Researcher 33:14-26.

Kassam, L, A Dorward. 2017. A comparative assessment of the poverty impacts of pond and cage aquaculture in Ghana. Aquaculture 470:110-122.

Kongkeo, H, FB Davy. 2010. Backyard hatcheries and small scale shrimp and prawn farming in Thailand. Success stories in Asian aquaculture. Singapore: Springer.

Kurien, J. 1991. Ruining the commons and responses of the commoners: Coastal overfishing and Fishermen's actions in Kerala state, Indian, 23.

Lebel, L, NH Tri, A Saengnoree, S Pasong, U Buatama, LK Thoa. 2002. Industrial transformation and shrimp aquaculture in Thailand and Vietnam: Pathways to ecological, social, and economic sustainability? Ambio: A Journal of the Human Environment 31:311-323.

Marschke, M., Armitage, D., Van tuyen, T. \& Mallee, H. 2012. Do collective property rights make sense? Insights from central Vietnam. International Journal of the Commons, 6.

Marschke, M, G Betcherman. 2016. Vietnam's seafood boom: Economic growth with impoverishment? Environment, Development and Sustainability 18:1129-1150.

Marshall, J. 2001. Landlords, leaseholders \& sweat equity: Changing property regimes in aquaculture. Marine Policy 25: 335-352.

Militz, TA, S Foale. 2017. The "Nemo effect": Perception and reality of finding Nemo's impact on marine aquarium fisheries. Fish and Fisheries 18:596-606.

NAQDA. 2017. National Aquaculture Development Authority of Sri Lanka [Online]. Available: http://www.naqda.gov.Ik statistics/Production-of-Shrimp/ Accessed February 072017.

Nayak, PK, F Berkes. 2010. Whose marginalisation? Politics around environmental injustices in India's Chilika lagoon. Local Environment 15:553-567.

Nayak, PK, F Berkes. 2011. Commonisation and decommonisation: Understanding the processes of change in the Chilika lagoon, India. Conservation and Society 9:132.

Naylor, RL, RJ Goldburg, JH Primavera, N Kautsky, MC Beveridge, J Clay, C Folke, J Lubchenco, H Mooney, M Troell. 2000. Effect of aquaculture on world fish supplies. Nature 405:1017-1024.

Nielsen, R, F Asche, M Nielsen. 2016. Restructuring European freshwater aquaculture from family-owned to large-scale firms-lessons from Danish aquaculture. Aquaculture Research 47:3852-3866.

Ostrom, E. 1990 Governing the commons: The evolution of institutions for collective action. New York: Cambridge University Press.

Ostrom, E. 2007. A General Framework for Analyzing Sustainability of Social-Ecological Systems. In Proc. R. Soc. London Ser. B, 274:193.

Ostrom, E. 2014. Collective action and the evolution of social norms. Journal of Natural Resources Policy Research 6 235-252.

Ostrom, E, J Burger, CB Field, RB Norgaard, D Policansky. 1999. Revisiting the commons: Local lessons, global challenges. Science 284:278-282.

Oviedo, AF, M Bursztyn. 2016. The fortune of the commons: Participatory evaluation of small-scale fisheries in the Brazilian Amazon. Environmental Management 57:1009-1023.

Pathirana, K., Kamal, A., Riyas, M. \& Safeek, A. 2008. Management of coastal resources in Puttalam lagoon, Sri Lanka. Paper No: P-06 COPEDEC VII.

Pauly, D, D Zeller. 2017. Comments on FAOs state of world fisheries and aquaculture (SOFIA 2016). Marine Policy 77: $176-181$.

Peluso, N. L. 2007. Enclosure and privatization of neoliberal environments. In N. Heynen, J. McCarthy, S. Prudham and P. Robbins (eds) Neoliberal environments: False promises and unnatural consequences, Routledge, Oxon, pp. 89-93.

Poteete, A. R., Janssen, M. A. \& Ostrom, E. 2010. Working together: collective action, the commons, and multiple methods in practice, NJ, Princeton University Press.

Pradhan, D, M Flaherty. 2007. National initiatives, local effects: Trade liberalization, shrimp aquaculture, and coastal communities in Orissa, India. Society \& Natural Resources 21:63-76.

Primavera, JH. 1997. Socio-economic impacts of shrimp culture. Aquaculture Research 28:815-827.

Sundström, A. 2013. Corruption in the commons: Why bribery hampers enforcement of environmental regulations in south African fisheries. International Journal of the Commons 7:454-472

Tovar, A, C Moreno, MP Mánuel-vez, M García-vargas. 2000. Environmental impacts of intensive aquaculture in marine waters. Water Research 34:334-342.

Umesh, N., Mohan, A. C., Ravibabu, G., Padiyar, P., Phillips, M., Mohan, C. \& Bhat, B. V. 2010. Shrimp farmers in India: Empowering small-scale farmers through a cluster-based approach. In: Success stories in Asian aquaculture. C De Silva, FB Davy, editors. Ottawa: Springer. 